Erratum

\title{
Erratum to "Effects of Exercise Training on Fat Loss and Lean Mass Gain in Mexican-American and Korean Premenopausal Women"
}

\author{
Shenghui Wu $\left(\mathbb{D},{ }^{1}\right.$ Kyung-Shin Park $\mathbb{D},{ }^{2}$ and Joseph B. McCormick ${ }^{3}$ \\ ${ }^{1}$ Department of Epidemiology \& Biostatistics, University of Texas Health Science Center at San Antonio-Laredo Campus, \\ Laredo, TX 78041, USA \\ ${ }^{2}$ Kinesiology, Texas A\&M International University, 5201 University Blvd., Laredo, TX 78041, USA \\ ${ }^{3}$ Division of Epidemiology, School of Public Health, Brownsville Campus, University of Texas Health Science Center-Houston, \\ Brownsville, TX 78520, USA \\ Correspondence should be addressed to Shenghui Wu; wus@uthscsa.edu
}

Received 28 April 2019; Accepted 12 May 2019; Published 27 May 2019

Copyright (C) 2019 Shenghui Wu et al. This is an open access article distributed under the Creative Commons Attribution License, which permits unrestricted use, distribution, and reproduction in any medium, provided the original work is properly cited.

In the article titled "Effects of Exercise Training on Fat Loss and Lean Mass Gain in Mexican-American and Korean Premenopausal Women" [1], during the production stage, there was a typing error in the Abstract and Conclusions sections, as the sentence "Exercise training had a beneficial effect on reducing BMI, fat percentage, fat mass, and visceral adipose tissue area but had no effect on increasing lean mass for Mexican-American and Korean premenopausal obese women" should be corrected as follows:

"Exercise training had a beneficial effect on reducing $\mathrm{BMI}$, fat percentage, fat mass, and visceral adipose tissue area but increasing lean mass for Mexican-American and Korean premenopausal obese women."

\section{References}

[1] S. Wu, K.-S. Park, and J. B. McCormick, "Effects of exercise training on fat loss and lean mass gain in mexican-american and korean premenopausal women," International Journal of Endocrinology, vol. 2017, Article ID 5465869, 7 pages, 2017. 


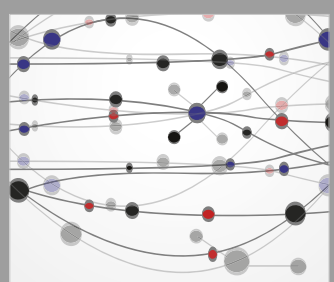

The Scientific World Journal
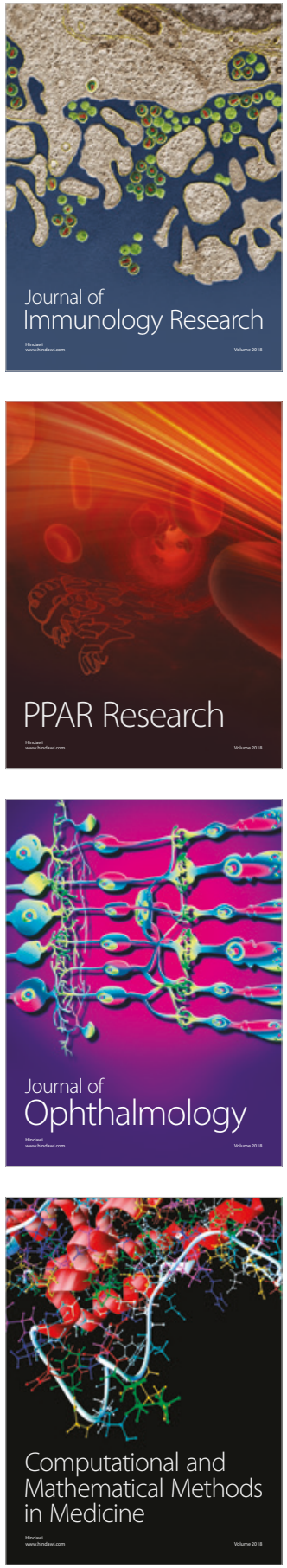

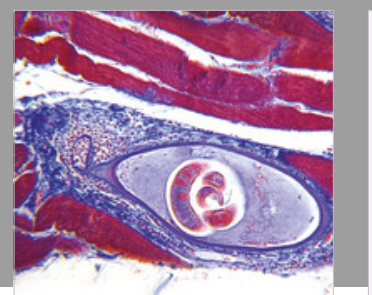

Gastroenterology Research and Practice

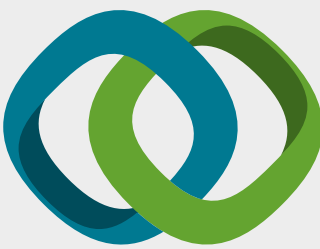

\section{Hindawi}

Submit your manuscripts at

www.hindawi.com
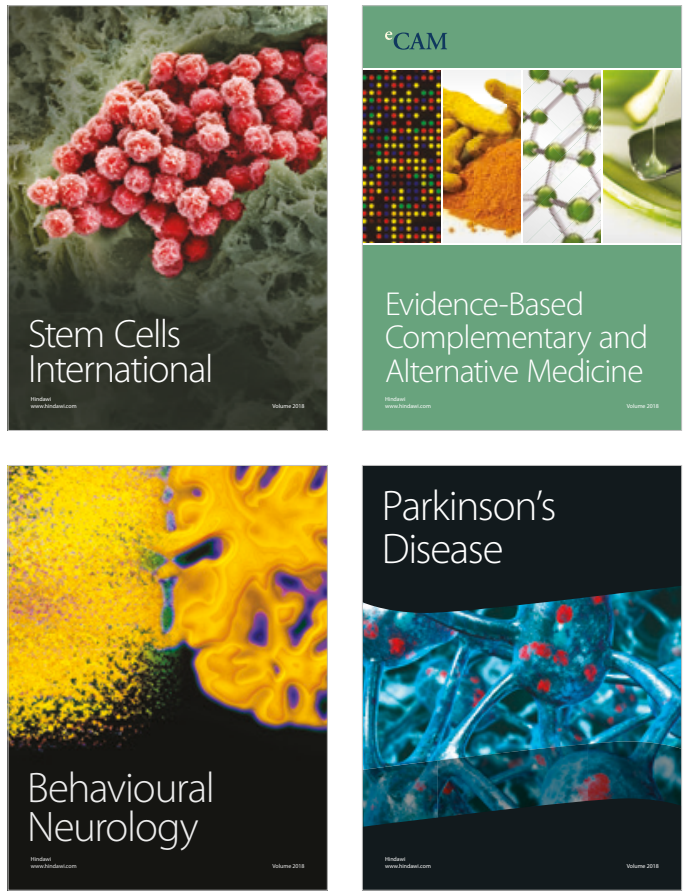

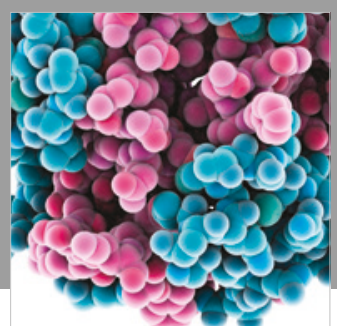

ournal of

Diabetes Research

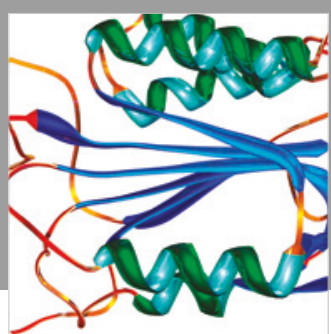

Disease Markers
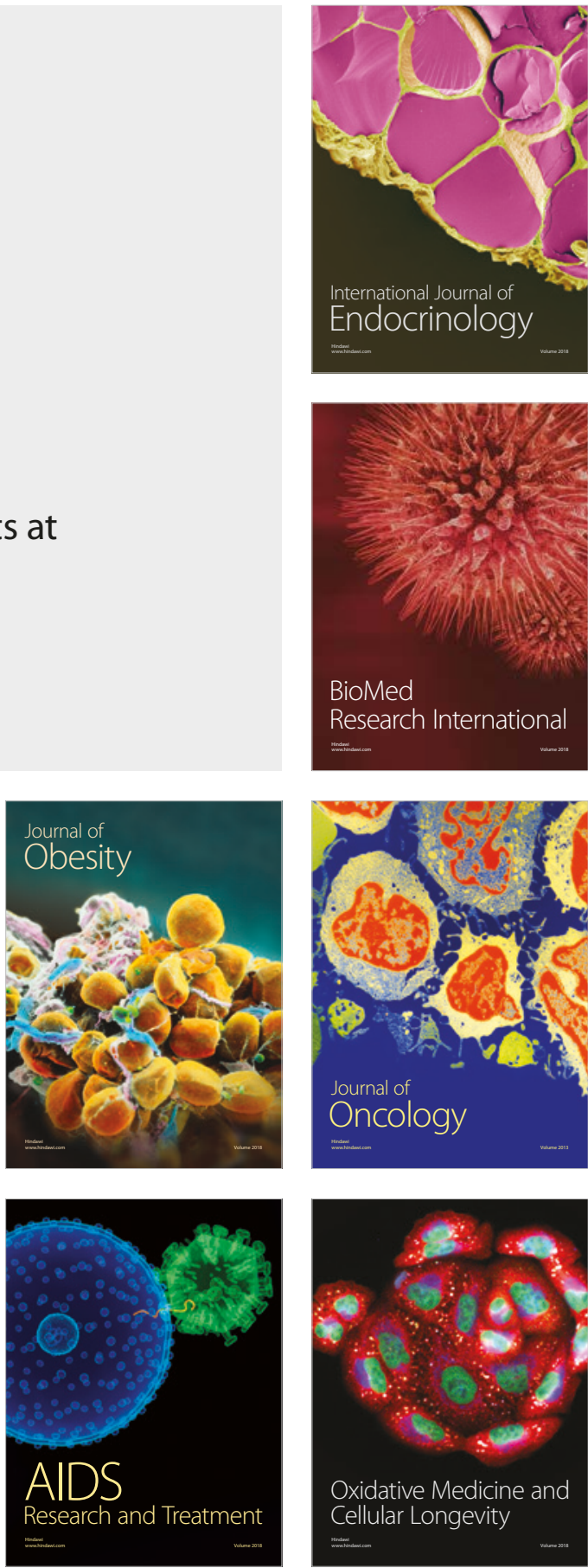